\title{
PORTRAITS OF A PARTHIAN KING: ROCK-RELIEFS AND THE MOUNTAIN FORTRESSES OF RABANA-MERQULY IN IRAQI KURDISTAN $^{1}$
}

\author{
By Michael Brown, Peter Miglus, Kamal Rasheed and Mustafa Ahmad
}

\begin{abstract}
This article presents detailed illustrations of two rock-reliefs from the neighbouring sites Rabana and Merquly, located on the flanks of Mt. Piramagrun in Iraqi Kurdistan. Both matching sculptures are aligned with perimeter fortifications that enclose substantial architectural remains. Based on numismatic parallels, supported by archaeological evidence, it is proposed that these depictions of near life-size figures represent an anonymous Arsacid King of Kings from the early first millennium (c. A.D. 50-150), who was credited with construction of the mountain fortresses. Rabana and Merquly together form an important landscape of settlement on the north-western frontier of the Parthian Empire.
\end{abstract}

\section{Introduction}

The twin fortresses of Rabana-Merquly (Kurdish: رهبمنه-ميرقولى) in the Zagros Mountains of Iraqi Kurdistan initially came to the attention of archaeologists through their matching rock-reliefs, which appear to depict a Parthian ruler (Fig. 1). Concise studies of these sculptures and their surroundings have been published by Mahdi (1950: 240-41), Rasheed (2001), Amedie and Zamua (2011), Ahmed (2012: 293-95) and Amin (2016). The adjacent settlement at Merquly was excavated in 2009 by the Sulaimaniyah Directorate of Antiquities, revealing a citadel and associated structures (Saber et al. 2014). In 2016-17, with the documentation of monumental architecture and an extensive fortification system at nearby Rabana, it was determined that both sites constitute a single cluster of occupation. This can in turn be related to long-distance communications and the region's wider historical geography.

The Parthian Empire was founded by the Arsacid dynasty and rose to become the dominant political and military power in Persia and neighbouring parts of eastern Mesopotamia for nearly half a millennium (c. 250 B.C.-A.D. 226) (Bivar 1983; Debevoise 1938). Parthia played a formative role in the development of the Eurasian world-system through pioneering relations with Rome and Han China (Ball 2000: 8-9, 12-15; Tao 2007). Despite its evident significance, our knowledge of Parthian history and archaeology remains woefully incomplete. This is in part due to investigative bias, studies of Persian civilisation in antiquity traditionally being of peripheral interest to Classical and Near Eastern scholars alike, combined with a paucity of primary textual sources. Such evidentiary shortcomings are exacerbated in Iraqi Kurdistan, where archaeological examination of Parthian contexts has hitherto been limited. As the most westerly part of the Zagros Mountains, this region has always been important in structuring east-west and highlandlowland interactions. During the early first millennium A.D., Rabana-Merquly was located close to the border between the satrapy (or province) of Media and the vassal kingdom of Adiabene, on the frontline between Parthian and Roman spheres of influence (Kennedy 1996: 70-71, 83, 88). The overall aim of this research is to contextualise the rock-reliefs within their surrounding

\footnotetext{
${ }^{1}$ Fieldwork at Rabana-Merquly in 2016-17 was conducted as part of the Rock-Reliefs of Iraqi-Kurdistan Project, a collaboration between Heidelberg University and the IraqiKurdistan Directorate of Antiquities, funded by the Gerda Henkel Stiftung. Particular thanks are due to Juan Aguilar who produced $3 \mathrm{D}$ models of the sculptures and took aerial photographs together with Jarek Piech, to whom we are also grateful. Maps were drawn by Michael Brown with help from Leonie Schmidt. The authors likewise acknowledge
}

the hard work and assistance of Jumana Alasaad, Ulrike Bürger, Roxana Dörr and Jan Heiler (Heidelberg University), together with the staff of the Sulaimaniyah Antiquities Service, especially Najmaden Ahmad, Rebin Mohammed Rashid and Omar Mohammed Ali. The 2009 excavations at Merquly were directed by Zuhair Rajab and Abdul Rahman Muhammad Ali, to whom, along with Saber Ahmed Saber and Mark Altaweel, we extend our appreciation. 


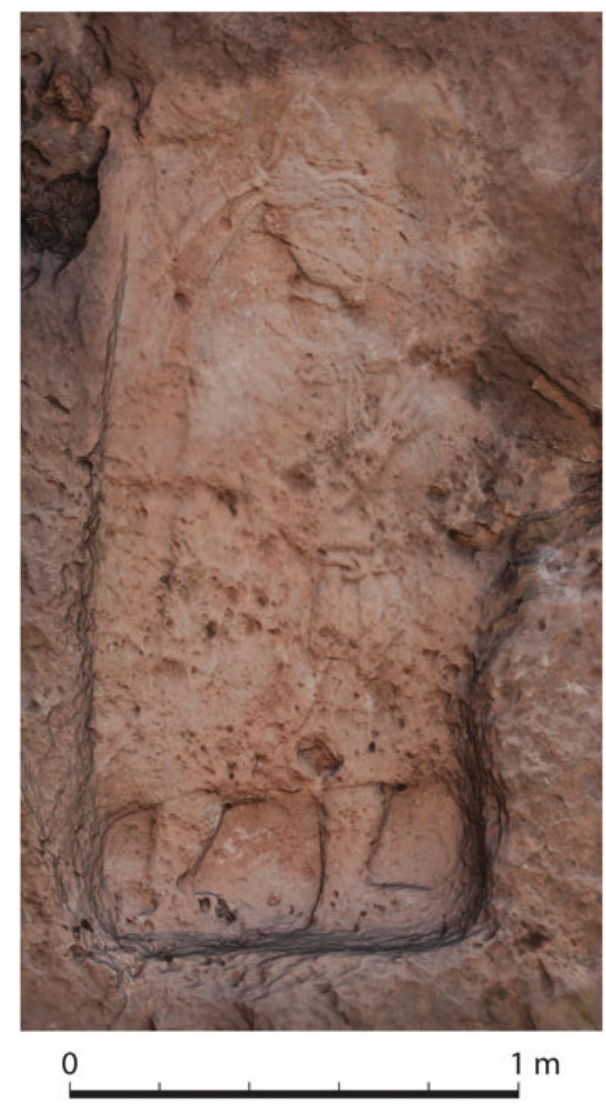

Fig. 1 Rabana rock-relief orthophoto (photogrammetry by J. Aguilar).

landscape, and in doing so to attempt to answer the questions of who built the mountain fortresses of Rabana-Merquly and why?

\section{Fortifying a Highland Landscape}

Rabana and Merquly are located 1.5 kilometres apart on the western side of Mt. Piramagrun (Kurdish: يير مجمكرون), one of the most prominent massifs in the Zagros Mountains (Fig. 2). With a maximum elevation of 2624 metres, this is the region's highest peak, which has led to its association with landfall after the flood in the Epic of Gilgamesh (George 2003: 516). In common with much of the wider Zagros, this landform primarily results from the last phase of Pleistocene glaciation, acting upon Mesozoic (dolomitic-marly) limestones of the Piramagrun anticline, followed by the formation of Pleistocene-Holocene piedmont (Sissakian and Fouad 2014; Wright 2004). A particularly prominent geomorphological feature is a rockslide of 3.5 kilometres in length emanating from the small U-shaped valley called Qulla-Rash that separates Rabana and Merquly (Karim et al. 2000). This rockslide is especially notable for its size, which at 200 million metric tons is the largest such recorded feature in northern Iraq.

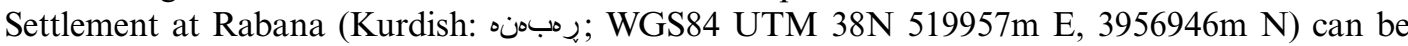
viewed as an extension of the surrounding highland landscape (Fig. 3). Occupation was concentrated inside the valley, which is encompassed by an arête or sharp glacial ridge to the south and west, and sheer cliffs to the north-east. This terrain presents a formidable barrier, restricting passage through the mountain. Where gaps in the rock at the valley base and along its upper ridges allow access, walls and rectangular towers were constructed to block intruders (Fig. 4), comparable in design to defences at Hatra (Bergamini 1987: 197). The overall result was a fortified enclosure of $c .26$ hectares that could be readily defended on all flanks. 


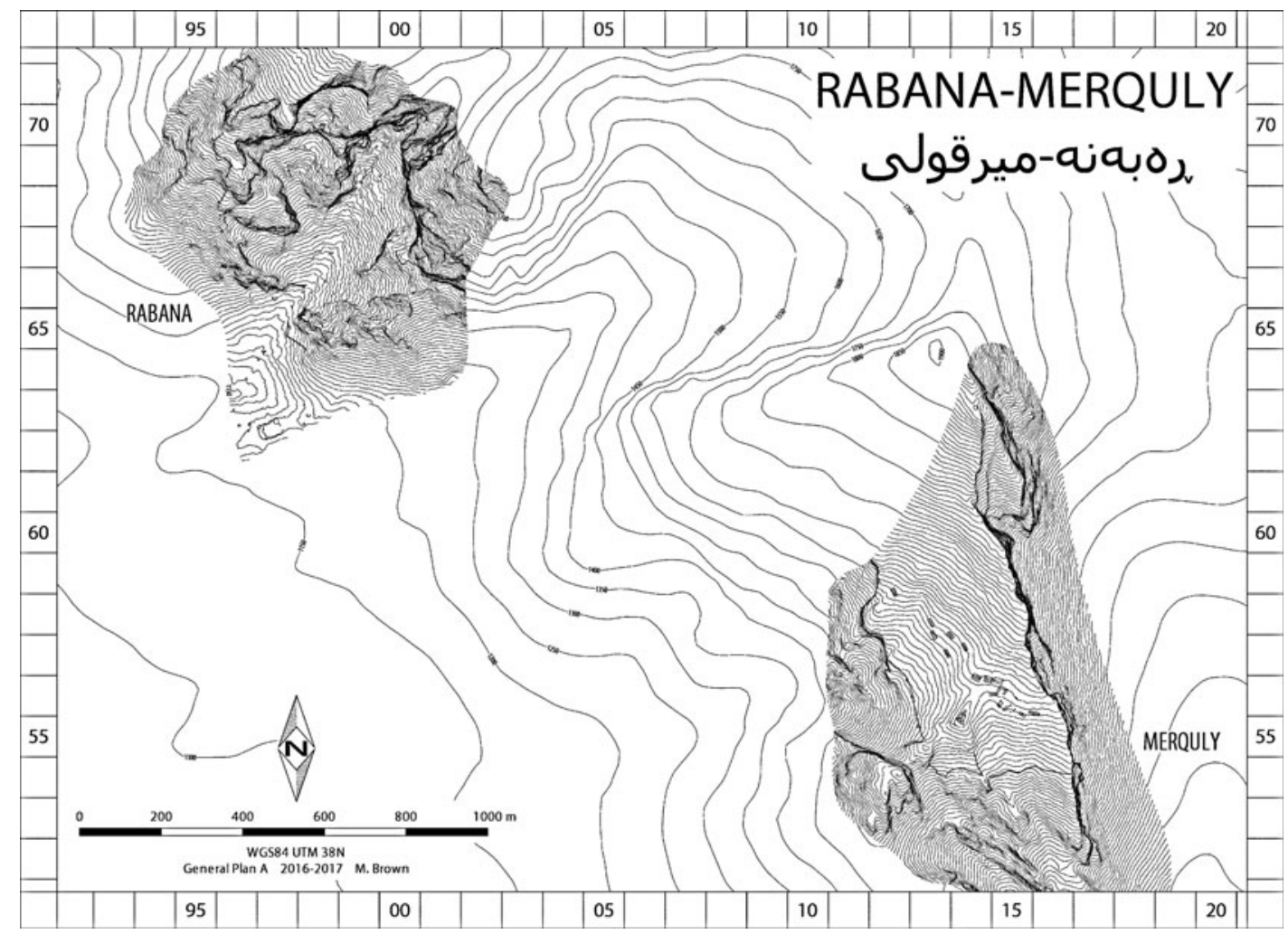

Fig. 2 Rabana-Merquly settlement cluster. Elevations in metres above sea level (m.a.s.1.) (map by M. Brown).

The main entrance into Rabana valley is from the south-west, where the bedrock has been eroded by a wadi, which ran through and was a defining topographical feature of the ancient settlement. This break in the site's natural perimeter was well defended by architectural augmentations, thereby allowing it to function as a 'gate'. The best preserved of these is a large wall on the south side that forms the front of a platform or building foundation subdivided with internal walls (Fig. 5). Prominently displayed on the adjacent cliff is one of the two rock-reliefs.

Behind the perimeter fortifications, the focus of occupation was in the east of Rabana. This area has a comparatively gradual slope, which was in several places levelled through terracing. Where the watercourse enters the valley from a narrow gorge extending high up into the mountain, it has been canalised with a combination of rock-cut and rough-stone architecture. Near to the wadi inlet is a subrectangular niche with an interior feature carved into the rock (Fig. 6). While this sculpture is incomplete, similarities with Parthian era cultic installations at Assur and Uruk-Warka suggest an altar (Andrae and Lenzen 1933: 70-71, pl. 36; Jordan 1928: 36-38, pls. 14, 43b, 73a). Excavations in 2017 revealed a stone staircase cut into the bedrock, which originally connected a building to the wadi (Fig. 7). With broad steps suitable for seating, this feature also recalls small theatra associated with Parthian era temples at Seleucia on the Tigris and at other contemporary Persian sites (Hopkins 1972: 119-26, 173; Hopkins 1942: 17-18). An adjacent steeper flight of narrow steps, which does not connect with the staircase, may have functioned as a water cascade. The overall impression is of a sanctuary complex, with a hydrological component that can be compared to Graeco-Roman nymphaea. Above and west of the staircase, a path connects with fortifications on the north-west side of the valley.

Merquly (Kurdish:ميرقولى; WGS84 UTM 38N 521432m E, 3955598m N) is located at the southern end of a high plateau, overlooking a narrow pass to a small valley within Mt. Piramagrun. This montane terrain was again augmented with walls, towers and terraces, expanding the area suitable for occupation and facilitating its defence. At the centre of the site is a citadel positioned atop a 


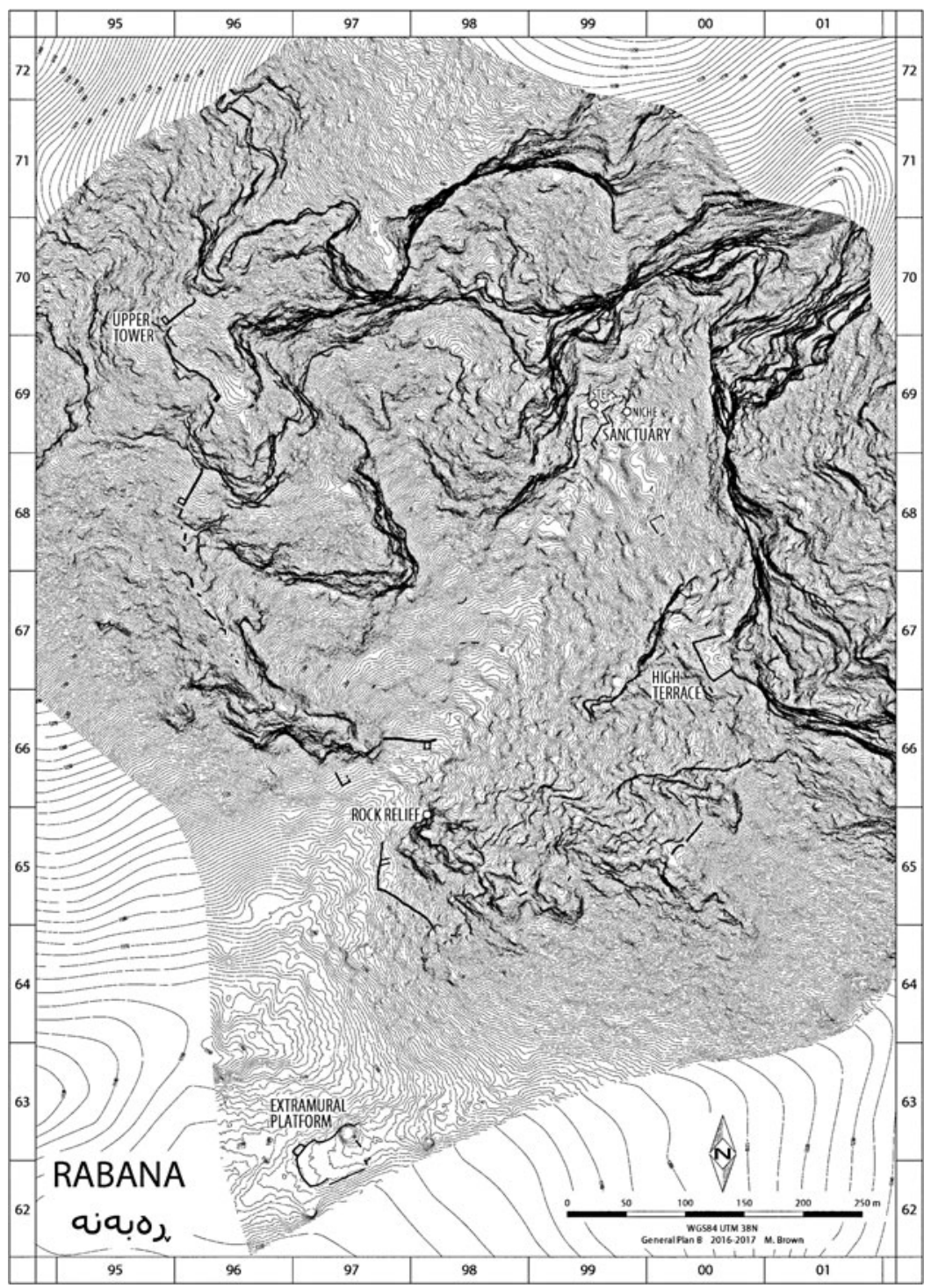

Fig. 3 Rabana settlement. Elevations m.a.s.l. (map by M. Brown).

natural outcrop (Saber et al. 2014: 231-36). To the north and east are various associated buildings. Merquly has one main phase of construction, which also appears to be the case at Rabana. Some minor renovation of the Merquly citadel occurred during the Parthian or Sasanian periods (Saber et al. 2014: 236).

South-west of and below the Merquly citadel is the second rock-relief (Fig. 8). As with its counterpart from Rabana, the Merquly rock-relief was aligned with adjacent perimeter fortifications and may again have been located near an entrance, even if the precise point of ingress is unclear. Sections of perimeter wall and escarpment indicate a total intramural area of $c$. 20 hectares, with a more densely occupied zone east of the citadel. While Merquly is currently accessed along a track coming west from Zewe village, a southern or eastern ascent is also possible, which is reflected in the orientation of the site's defences.

\section{Portraits of a King}

Defining features of Rabana and Merquly are their matching, approximately life-size rock-reliefs, each showing a bearded man in ornate attire (Figs. 9-10). Both sculptures are in good condition, 


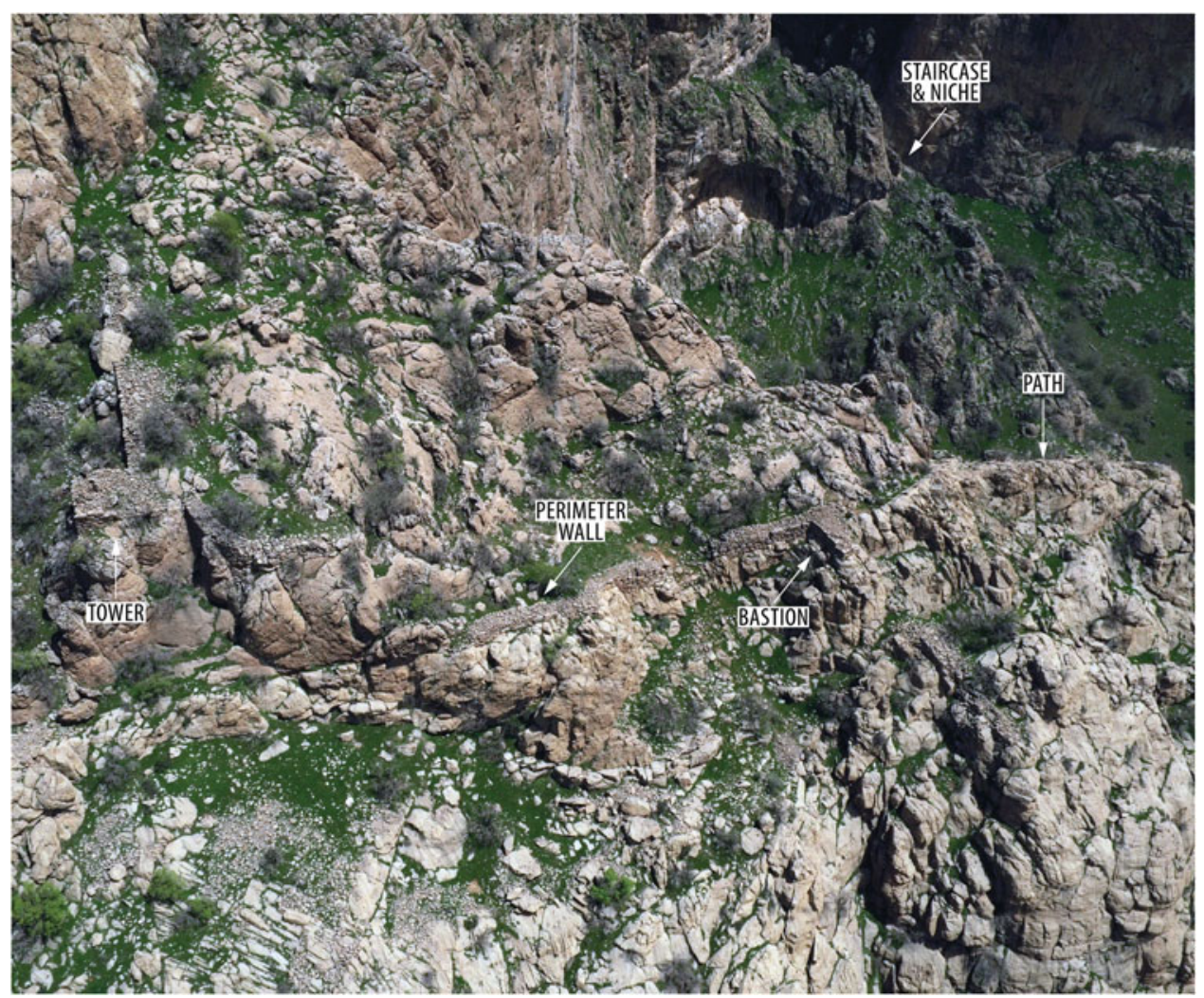

Fig. 4 Upper fortifications at Rabana facing east (photo by J. Aguilar and J. Piech).

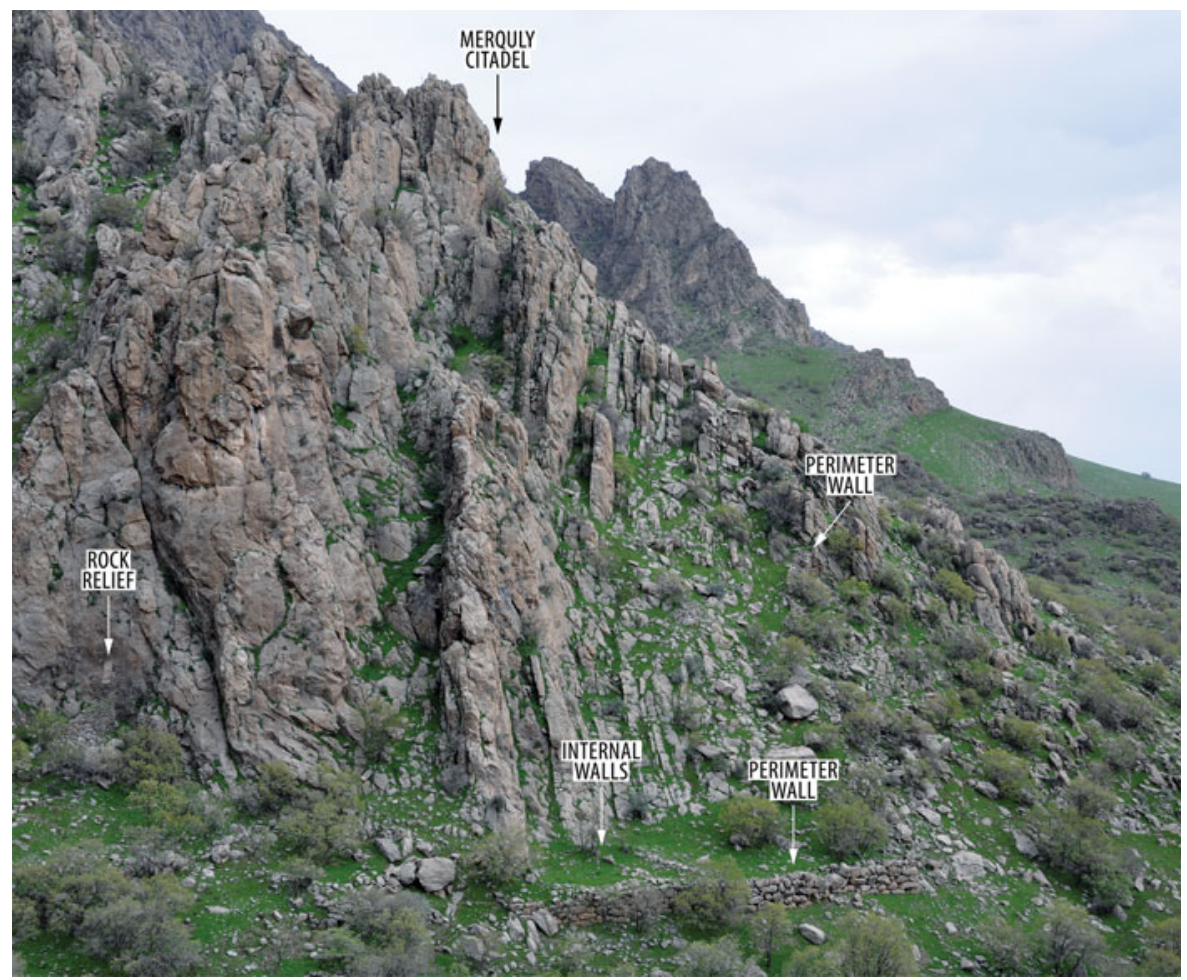

Fig. 5 Entrance to Rabana valley facing south-east (photo by M. Brown). 

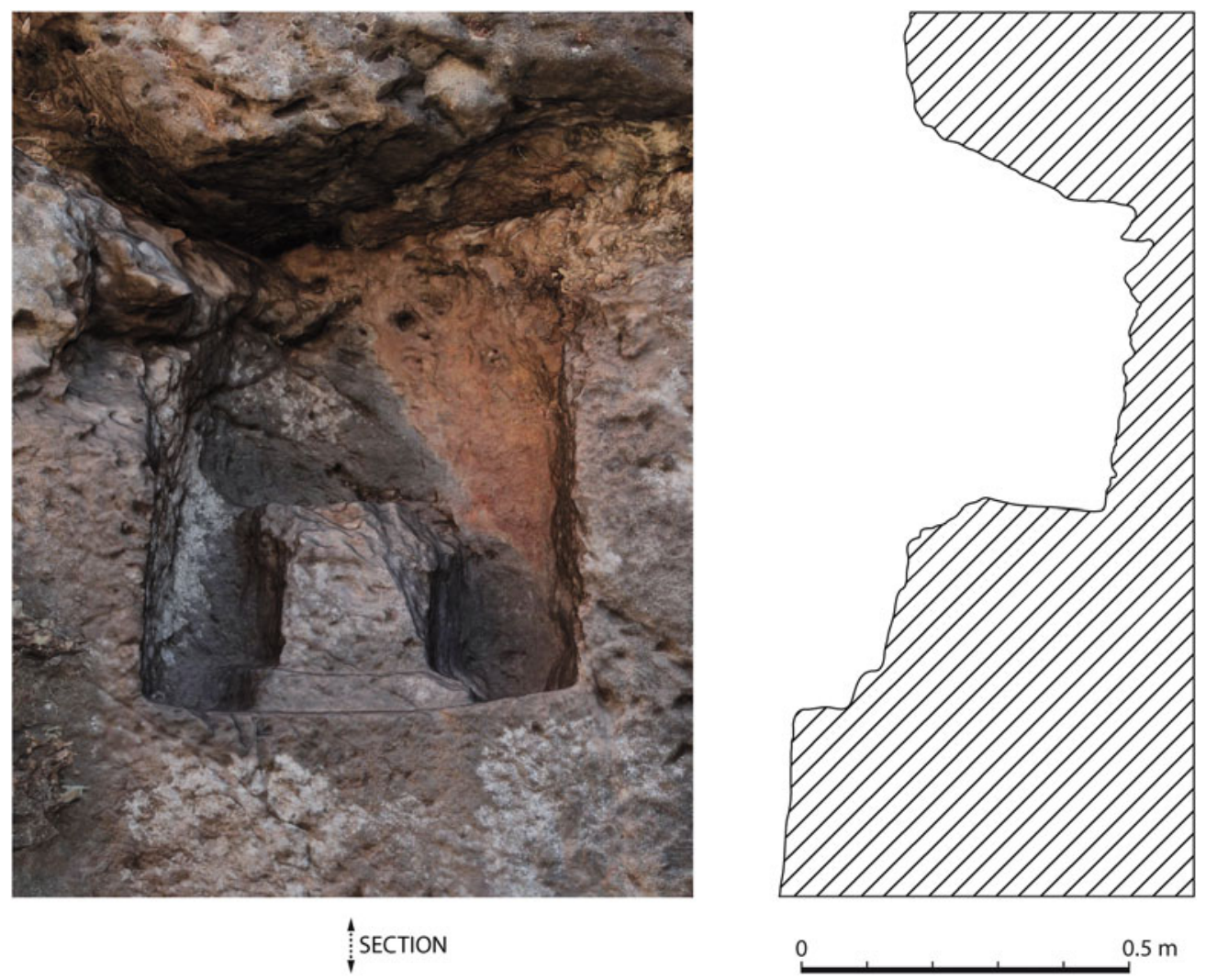

Fig. 6 Rabana rock-cut niche. Front view and section (photogrammetry by J. Aguilar, drawing by M. Brown).

having recently been cleaned in preparation for moulds taken to produce casts now displayed in the Sulaimaniyah Museum (Rasheed 2001). Erosion and minor damage to the rock-reliefs make it difficult to discern some details with the naked eye alone. Accordingly, photogrammetry was used to produce clearer images based on high-resolution 3D models. Lack of accompanying inscriptions makes it impossible to directly identify the individual(s) depicted. Informed speculation is, however, possible based on typological and stylistic attributes, combined with contextual information derived from archaeology.

Both figures are identically dressed. Each wears a torc around his neck. A cloak or long-sleeved coat (kandys) reaches below the knees and is secured at the neck by means of a clasp (Curtis 1998). Underneath this outer garment, the figures appear to be wearing Parthian trouser-suits. Around the waist is a tied belt with two hanging tapered ends. Both men wear plain ankle-high shoes. They are shown in the same standing or walking pose, with their right arm raised in front to chest height with open palm. This stance resembles statues of kings and nobles from Hatra (Dirven 2008: 222-28), and the frontal depiction in relief of an Elymaean ruler at Tang-i Sarvak (Mathiesen 1992: 135-36). Next to the inside left(?) leg of the Rabana figure is what appears to be an abortive earlier line. The relative care with which the facial features are rendered, in comparison to their bodies, suggests that the Rabana-Merquly rock-reliefs could be portraits. Both figures likely depict the same person (Amedie and Zamua 2011: 236).

Because of potential numismatic parallels, the most diagnostic apparel shown in the rock-reliefs is headgear. Around the base of a tall hat (high tiara or kolah) is a narrow strip of fabric, known as a diadem, which is tied at the back with the two ends hanging down to just below shoulder height. A sub-triangular detail is clearly visible on the side of the Rabana hat, with fainter traces on the Merquly rock-relief. This shows either an adornment or upturned protective ear-flap. 


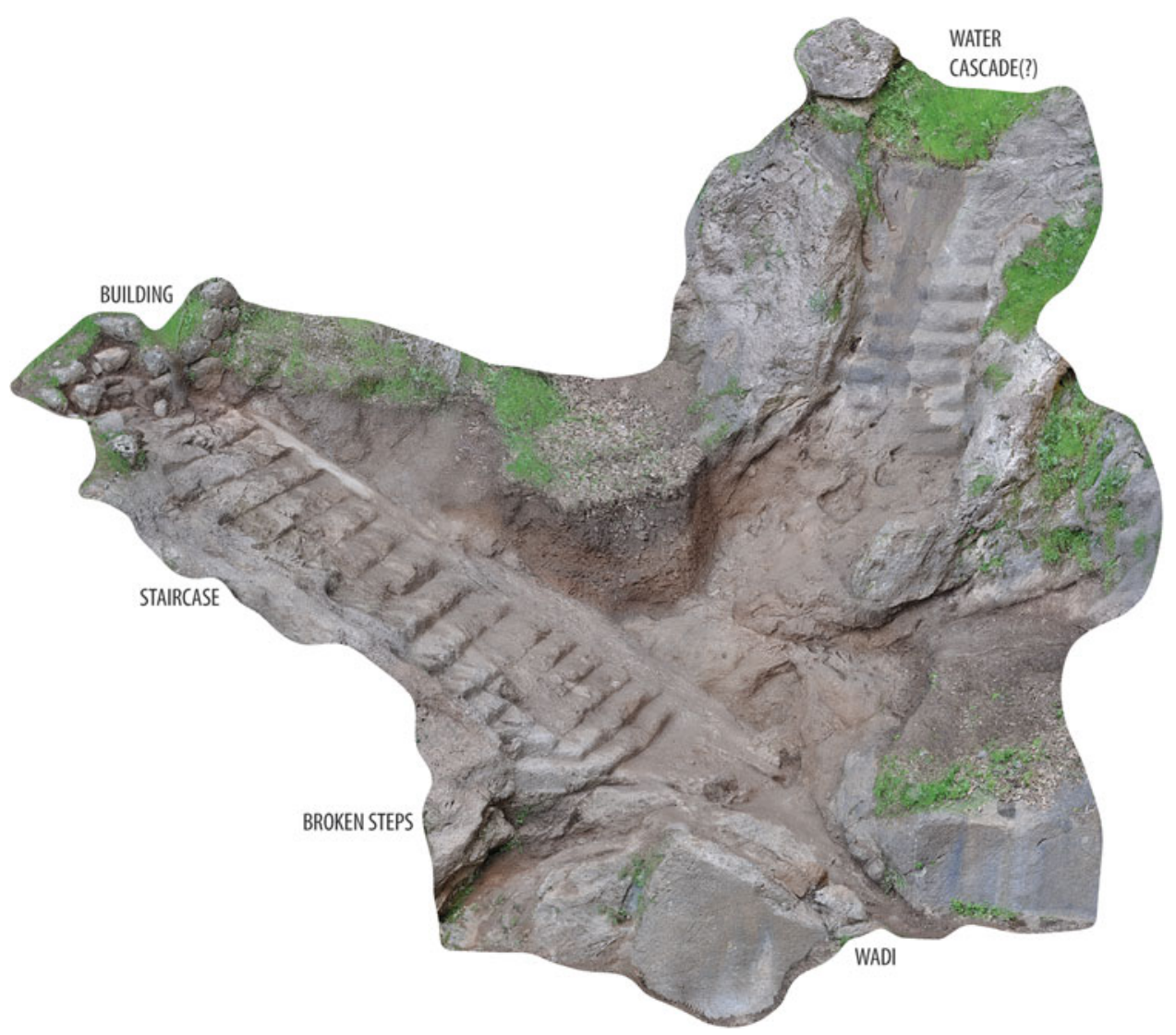

Fig. 7 Rabana sanctuary complex staircase and steps (photogrammetry by L. Schmidt).

The combination of diadem and tall hat is exclusively seen in depictions of Arsacid, as opposed to vassal, kings on Parthian coinage (Keller 2010: 624). Based on this iconographic trait, together with archaeological dating evidence for Rabana and Merquly (see 'Parthian Ceramics' below), it is possible to restrict the list of candidates to Parthian rulers of the first and second centuries A.D. Vonones II is credited with re-introducing the combination of tall hat and diadem on coinage after a century's hiatus (Sellwood 1971: type 67). If a further distinction is made between tall hats with hanging ear-flaps and those without, as at Rabana-Merquly, only three kings wear this latter style of tiara on coins: Vologaeses II (Sellwood type 72), Pacorus II (Sellwood type 77), and Vologaeses III (Sellwood type 79) (Mathiesen 1992: 81). Side tiara adornments are not seen on coins of Pacorus II. Attribution of coins to Vologaeses II, a putative son of Vologaeses I, is problematic due to uncertainties regarding his reign (LeRider 1965: 174-75). It should be noted that some Arsacid kings (e.g. Vologaeses III) are depicted on different coin issues both with and without a tiara. The tall hat is not associated with rulers of Adiabene, who are only shown on coins wearing the satrapial style of tiara (Marciak and Wójcikowski 2016).

An important stylistic trait of the Rabana-Merquly rock-reliefs is their depiction of figures in three-quarter view, which can be seen in the visibility of two eye sockets and both sides of the chest. This halfway transition from profile to frontality is characteristic of sculpture during the Middle Parthian period (c. A.D. 1-150) (Mathiesen 1992: 27-28; Schlumberger 1983: 1050-51). The closest source for comparison in terms of style, composition and geography is the rock-relief from Batas-Herir 50 kilometres north-east of Erbil (cf. Zamua 2009). This larger sculpture similarly depicts a male figure in ceremonial dress with his right arm raised. Significant differences include the satrapal tiara, profile perspective, and rectangular double border, all of which hint at a relatively early date. The Batas-Herir figure also holds a spear or staff in his left hand. Various 


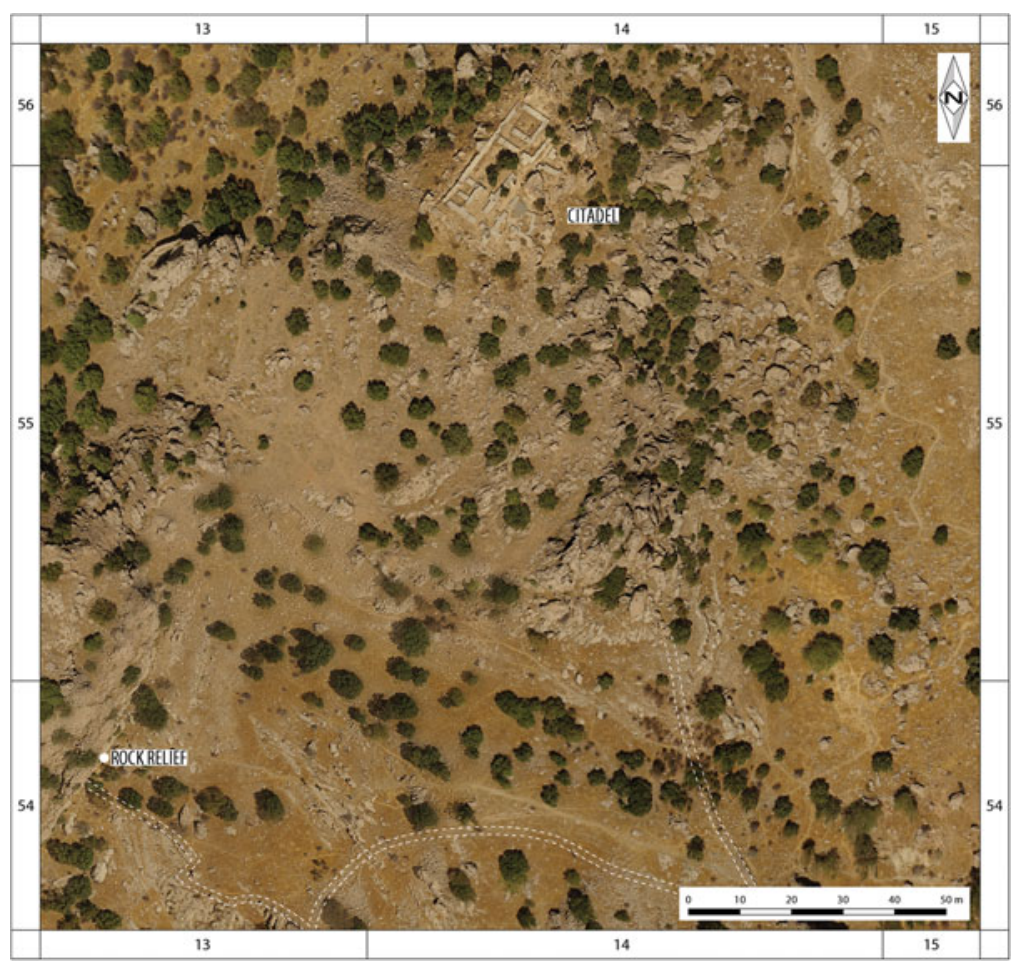

Fig. 8 Aerial orthophoto of Merquly showing location of rock-relief and citadel. Dashed line indicates perimeter fortifications (photography by J. Aguilar and J. Piech, GIS processing by M. Brown).

periods for the Batas-Herir rock-relief have been suggested, ranging from the first half of the second century B.C. (Grabowski 2011) to the mid-first century A.D. (Boehmer and von Gall 1973).

\section{Parthian Ceramics}

Excavation of the stone staircase at Rabana in 2017 produced a small homogenous ceramic assemblage that can be dated to the Parthian period. Most of the pottery consists of storage jar sherds. A distinctive feature is the coarse fabric of the paste, which is mainly gritty or mineral tempered by medium to large size inclusions of orange, gray, white, black and yellow colors, mixed with non-levigated clay. A few sherds are coated with bitumen on their interior faces, indicating that these jars were used for storing liquid. Very few cooking ware sherds were present, likely reflecting the non-domestic context under investigation.

Three large pithos rims were found, with a square-banded profile and the upper part of the lip deliberately pressed down to accommodate a lid (Fig. 11A). The coarse exterior surface of the rim and body was smoothed with a clayey layer, tempered with medium to large size white mineral inclusions. These rims are decorated with horizontal and wavy incised lines under the lip on the exterior. Body sherds from the same pithos are decorated with applied cords.

An exceptional storage jar rim has an over-rolled grooved profile (Fig. 11B). This form first appears in the Hellenistic period at Hatra (Venco Ricciardi 1997: fig. 4.47, 49, 53) and Nimrud (Oates and Oates 1958: pl. XXV.5-6) and continued into the Parthian era at Assur (Hauser 1994: pl. 155d-f) and Tell Barri (Palermo 2010: fig. 2a), with variations mainly in fabric. Our rim is dated to the Parthian period and has a gritty fabric with angular large brown minerals.

Two rims from bottles were recovered (Fig. 11C, E). A parallel for these is known from Parthian Assur (Hauser 1996: fig. 6d), and this type of rim is commonly found in Parthian levels at Iranian sites such as Qeshm Island (Khosrowzadeh 2014: fig. 10.1-5). Two further discrete concentrations of pottery have a distinct sand-tempered fabric with fine mineral inclusions (Fig. 11D). This material potentially dates from the Parthian to early Sasanian periods. 

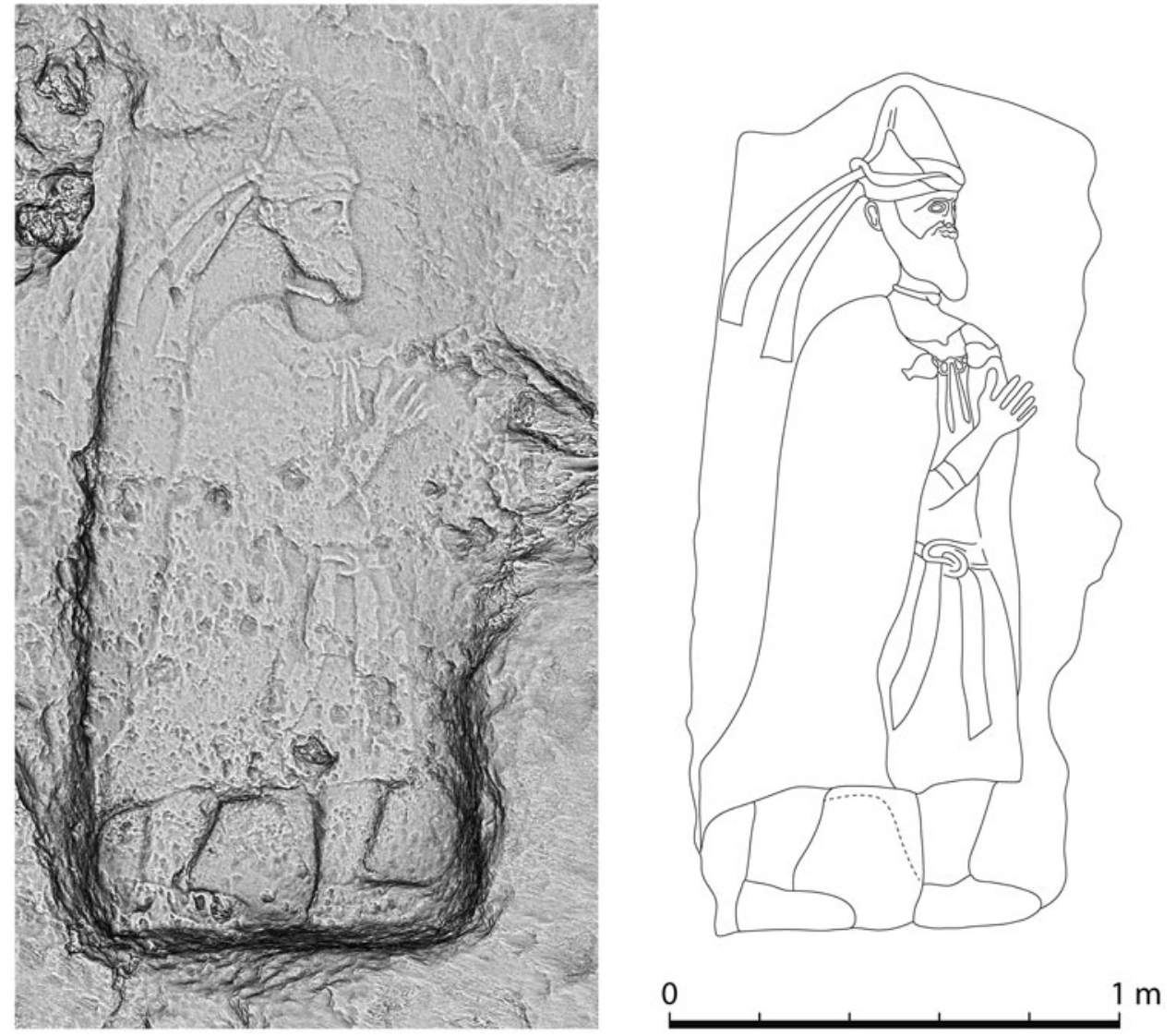

Fig. 9 Rabana rock-relief (photogrammetry by J. Aguilar, drawing by M. Brown and U. Bürger).

The range of ceramics found so far at Rabana compares well with material from Merquly, where several Parthian and transitional Partho-Sasanian types were also identified (Saber et al. 2014: 236-41). Of particular chronological significance are green-glazed ceramics from Merquly, diagnostic examples of which can be dated to between the first and third centuries A.D. based on Mesopotamian and Iranian parallels (Assur: Hauser 1994: pls. 136a, 225c-h; Seleucia on the Tigris: Debevoise 1934: figs. 141-143, 180; Iran: Haerinck 1983: pl. IV.3 (after Ghirshman 1962: 112, fig. 133a); Qeshm Island: Khosrowzadeh 2014: fig. 8). Further excavation at Rabana, combined with comparative re-analysis of the ceramics from Merquly, is required to clarify the respective chronology of these assemblages.

\section{The Parthian Frontier and the Persian Royal Road}

The physical topography of southern Iraqi Kurdistan is defined by the Lower Zab and Diyala (or Sirwan) rivers respectively to the north and south, the Mesopotamian lowlands in the west, and the Zagros Mountains to the east. Passage through this landscape is structured by four broadly parallel foothill and mountain ranges (Bazian + Qara Dagh - Baramand - Piramagrun - Azmar + Kurhakazhaw + Avroman) running NW-SE. These are punctuated by a series of passes and river tracks. The focus of occupation in ancient and modern times is the Tanjero river valley, the wider southern half of which is known as the Shahrizor plain. The intermontane area adjacent to Rabana-Merquly, roughly defined by the western flank of Mt. Piramagrun together with the Charmaga and connecting Surqawshan river valleys, is a northern extension of this system.

In the early first millennium A.D., the combined region most probably corresponds to a western sub-division of greater Media (Radner in Altaweel et al. 2012: 15), which first came under Arsacid 

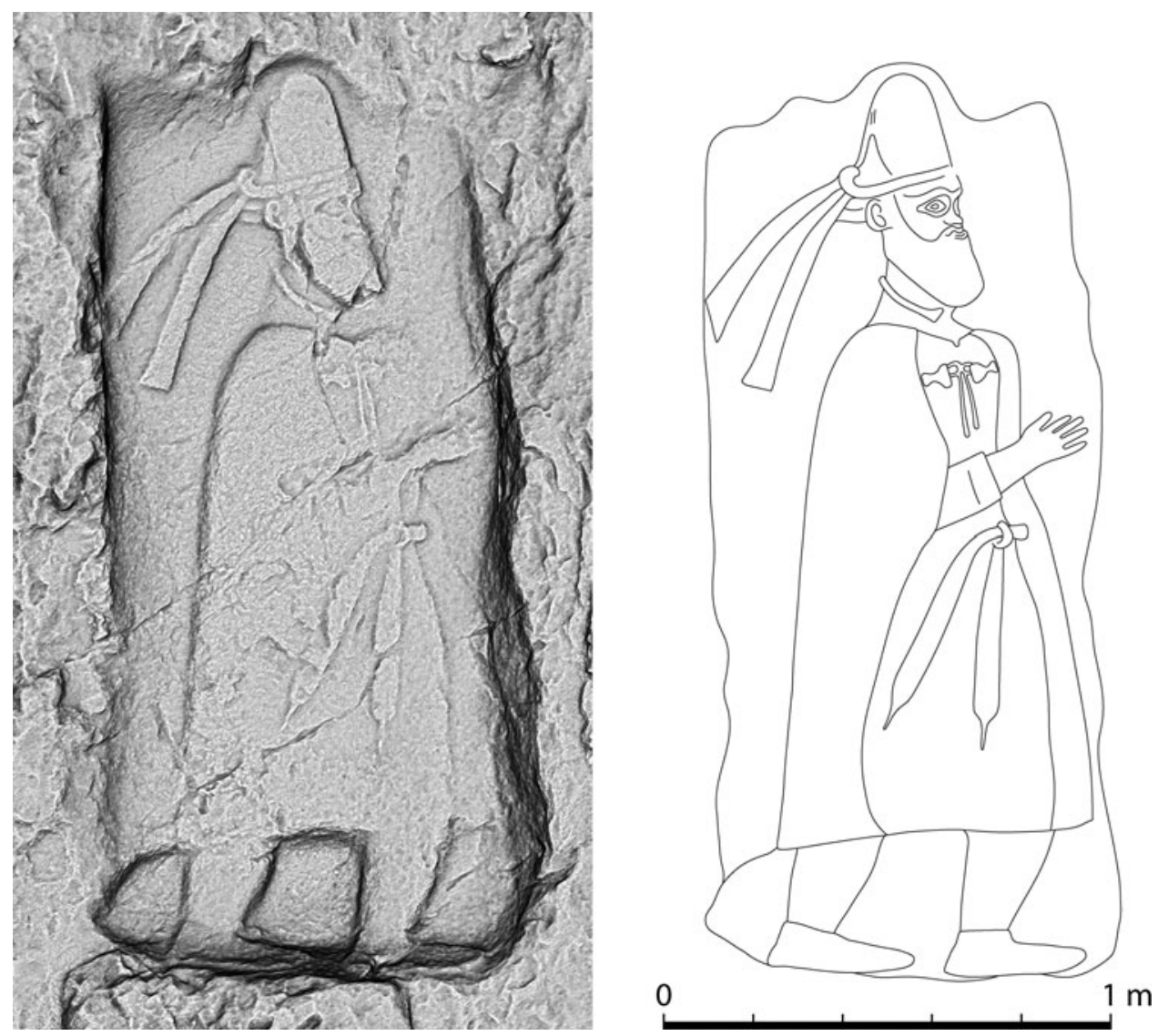

Fig. 10 Merquly rock-relief (photogrammetry by J. Aguilar, drawing by M. Brown and U. Bürger).

control in c. 148-141 B.C. when its capital Ecbatana (modern Hamadan) was conquered by Mithridates I (r. 171-139/8 B.C.). North-west of Media was the kingdom of Adiabene, the core territory of which surrounds its capital Arbela (modern Erbil) between the Upper and Lower Zab rivers. Although the Parthian conquest of Adiabene is not explicitly recorded in ancient texts, this vassal kingdom is known to have been under Parthian control from the time of Mithridates II (r. 124/3-88/7 B.C.) (Marciak 2017: 346-47). At various points during the ensuing three centuries of Arsacid dominion, the naturally defined border between Adiabene-Media (and Sittakene), which ran along the Lower Zab (classical Kapros) towards the Tigris, became a contested frontier between oriental and occidental powers. Specific instances include the abortive Parthian attack led by Vologaeses I on their rebellious vassal Adiabene under Izates II in A.D. 51, an unsuccessful Armenian invasion of Adiabene by Tigranes repulsed with Parthian support in A.D. 61, and Trajan's capture of Adiabene in A.D. 115 followed by Parthian resistance (Debevoise 1938: 177-78; 185-87; 230-31).

It has been conversely proposed by Amedie and Zamua (2011: 236) that Rabana-Merquly could represent a southern extension of Adiabene. Although the twin fortresses undoubtedly lay close to the border, this alternative hypothesis should arguably be rejected on the basis that the headgear depicted in the rock-reliefs favours an Arsacid attribution. In addition, while Adiabene annexed territory north of the Upper Zab during the later first century B.C. - earlier first century A.D. at the expense of neighbouring Gordyene (Marciak 2017: 270-71), it is important to note that this expansion occurred within the context of at least nominal Parthian overlordship and is thus less likely to have encompassed lands south of the Lower Zab that presumably belonged to Media and by extension the Parthian Empire. 


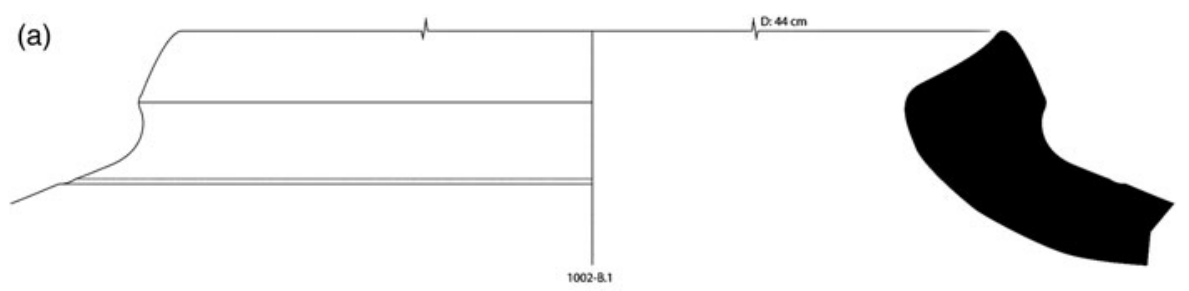

(b)

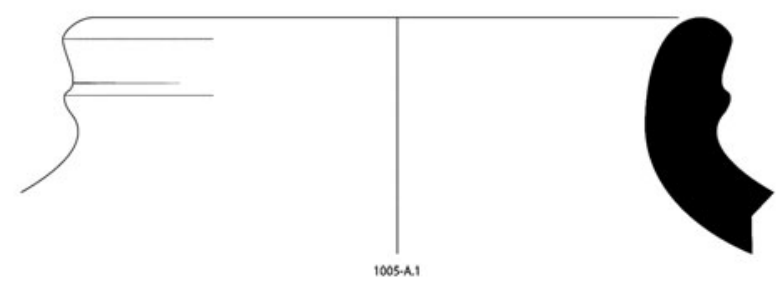

(c)

(d)

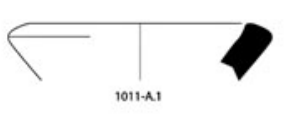

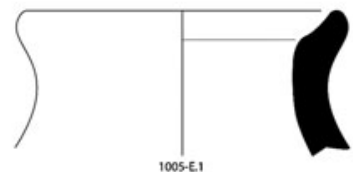

(e)
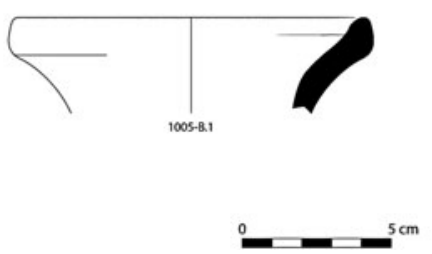

Fig. 11 Parthian ceramics from Rabana (drawings by M. Ahmad).

Traditional overland communications in southern Iraqi Kurdistan are summarised by Levine (1973: 10-14). During the Parthian period, most travellers coming from Arbela would have crossed the Lower Zab at Altun Kopri (Nováček 2016: 270-71), entering the Charmaga-Tanjero valley through the Bazian and Tasluja passes. At various points in its history the Bazian pass is recorded as being fortified (Amin Ali and Deroche 2016: 11-12). This route would have connected RabanaMerquly with the Royal Road between Sardis and Susa (Graf 1994: 179). Those continuing south towards the Parthian winter capital at Ctesiphon along the western flank of the Bazian ranges could have crossed the Diyala river either by boat (Herodotus 1.189, 5.52; Godley 1920) or via a precursor of the Sasanian era bridge near Jalula (Le Strange 1905: 62), where the Royal (later Khorasan) Road also turns east towards the Parthian summer capital of Ecbatana via the Zagros Gates. This strategically important pass was overlooked by a fortified complex of Late Parthian date 12 kilometres to the northeast at Qal'eh-i Yazdigird (Keall 1977; 1982). The valley entrance at Sar-i Pol-i Zohab is marked by a series of rock-reliefs, including one depicting an unknown Parthian King (Mathiesen 1992: 176-77). In both respects, this broadly contemporary settlement landscape bears conceptual comparison with that of Rabana-Merquly.

Alternative more direct routes into the Persian interior from Arbela, bypassing the defences of the Zagros Gates, are possible through southern Iraqi Kurdistan (Fig. 12). A second minor crossing over the Lower Zab further east at Arzlu was mapped by Speiser (1926-7: 23, 42), connecting with a path running above the right bank of the Surqawshan river. South of Rabana-Merquly two possible routes lead towards Kirmanshah on the Royal Road; down through the Sharizor plain to Halabja, and then up via the mountains into Iran; or through the Goyzha pass towards Lake Zeribor, running along the foothills of the Avroman Dagh. The antiquity of this latter way is demonstrated by the 'Avroman 


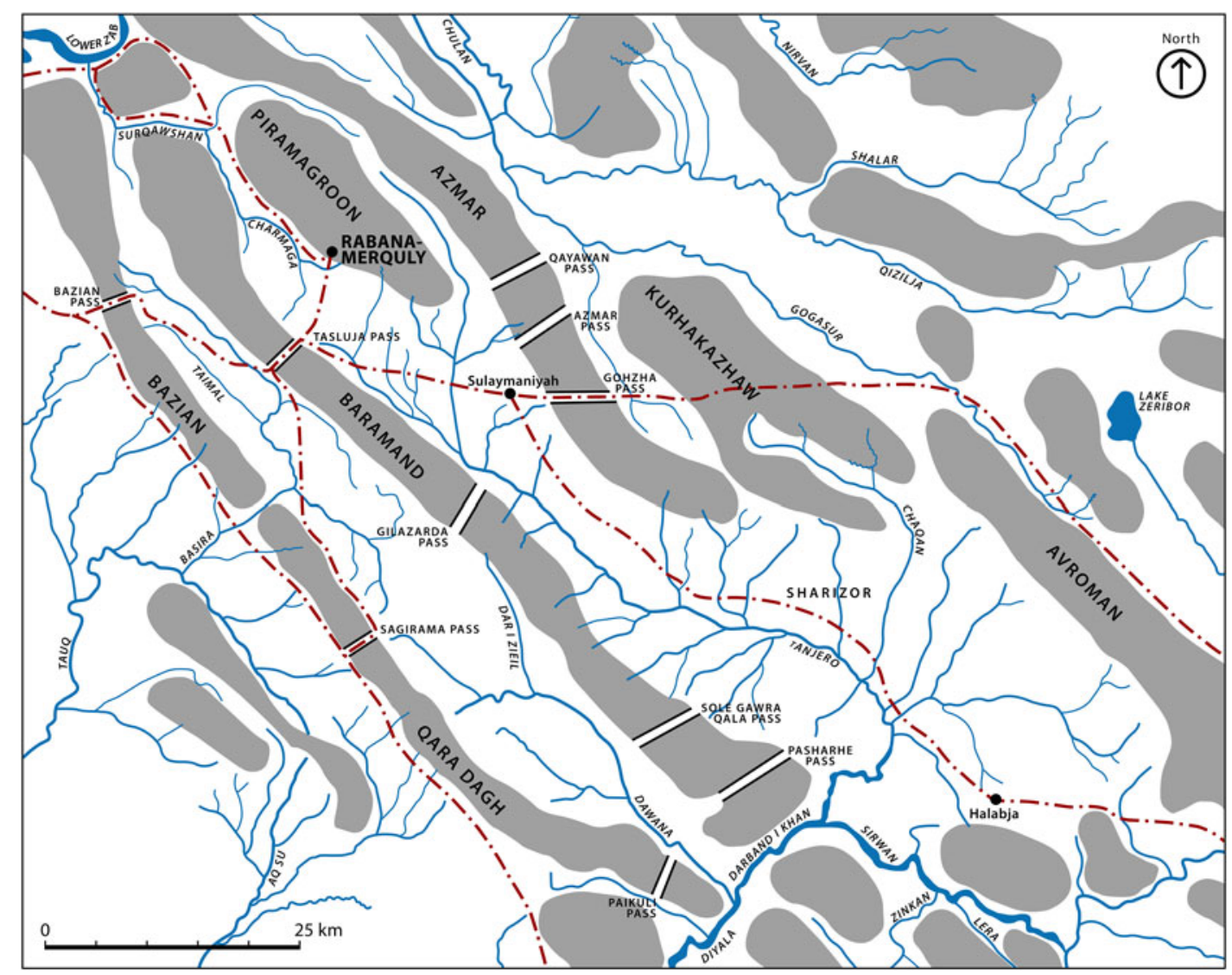

Fig. 12 Overland communications in southern Iraqi Kurdistan with routes mentioned in the text (map after Levine 1973: 11).

Parchments' of Parthian date, discovered in a cave at Kuh-e Salan on the Iranian side of the mountain (Edmonds 1952). A comparable network of Sasanian fortifications regulating overland passage at Bazian - Merquly(?) - Sitak - Kazhaw has been proposed by Tamm et al. (in press).

The potential vulnerability of Media to invasions emanating from the west during the later Parthian period offers a plausible explanation for the construction of fortifications on Mt. Piramagrun. Commanding views from the high towers at Rabana and the citadel at Merquly suggest that the position of these settlements related to controlling access into the CharmagaTanjero valley, providing their occupants with forewarning of an attack. A hypothetical frontier garrison stationed at Rabana-Merquly would have been well placed to respond to threats involving its immediate neighbour Adiabene, restive hill tribes, and Parthian possessions in Babylonia.

\section{Conclusions}

The mountain fortresses of Rabana-Merquly represent an important addition to our knowledge concerning the Parthian Empire. Stylistic and typological attributes of their rock-reliefs support a Middle Parthian (c. A.D. 50-150) foundation date. This interpretation is compatible with the combined ceramic assemblage, which indicates early first millennium A.D. settlement, most clearly during the Parthian period. Lack of evidence for more than one main architectural phase at either site suggests that the overall span of occupation was short-lived (c. 50 years or less). Close architectural and artefactual similarities between Rabana and Merquly, combined with their immediate proximity, imply contemporaneity. Limited renovation of the Merquly citadel, with its transitional pottery, leaves open the possibility of Sasanian reuse (cf. Saber et al. 2014: 241-42). 
Regarding the identity of the person(s) depicted on the rock-reliefs; the exclusive combination of tall hat and diadem indicate an Arsacid monarch. Rabana-Merquly was very likely located within Parthian territory during the early first millennium A.D., near to the north-west frontier of Media. As a satrapy under direct control of the empire, the most plausible candidate for the RabanaMerquly rock-reliefs is therefore a King of Kings. Positioning of the rock-reliefs shows an intentional association with perimeter fortifications at both sites. These planned defensive installations, which can in turn be linked to their intramural settlements, would have required substantial labour resources to build and maintain. We therefore propose that the rock-reliefs depict a ruler credited with their construction. Based on numismatic parallels, plausible candidates include Vonones II (r. A.D. 51) and his grandson Vologaeses III (r. A.D. 108/9-147/8) (Schottky 2006a; 2006b).

Extensive augmentation of natural terrain involved in the construction of Rabana-Merquly represents an anthropogenic extension of Mt. Piramagrun, which enhanced the strategic function of the western Zagros in protecting the Persian interior from incursion. While a holistic characterisation must await further investigation, the sanctuary complex at Rabana demonstrates it was not just a redoubt, but rather constituted part of a broader settlement landscape that very likely includes as yet unidentified sites on the adjoining floodplain. The relatively inaccessible location of Merquly atop a natural height may well reflect a specific military role associated with controlling access into the Charmaga-Tanjero valley. In more general terms, the mountain fortresses of Rabana-Merquly display many typical characteristics of highland landscapes in the ancient Near East, by being simultaneously isolated and acting as a frontier between larger polities (Wilkinson 2003: 184).

\section{Bibliography}

Ahmed, K. M. 2012. The beginnings of ancient Kurdistan (c. 2500-1500 BC): A historical and cultural synthesis. Unpublished PhD dissertation, Leiden University.

Altaweel, M., A. Marsh, S. Mühl, O. Nieuwenhuyse, K. Radner, K. Rasheed, and S. Saber. 2012. New Investigations in the Environment, History, and Archaeology of the Iraqi Hilly Flanks: Shahrizor Survey Project 2009-2011. Iraq 74: 1-35.

Amedie, E. M. and D. A. Zamua. 2011. "The Rock reliefs of Mirqulie and Rabanah in Bermațroon Mountains: An analysis and comparison". Subartu 4-5: 230-239 (in Arabic).

Amin, O. S. M. 2016. "Rock-reliefs of Mountain Merquli, Rabana and their nearby settlements, Iraqi Kurdistan". Available at: http://etc.ancient.eu/education/rock-reliefs-mountain-merquli-rabana-nearsettlements-iraqi-kurdistan (accessed 24 November 2017).

Amin Ali, N. and V. Deroche. 2016. "The site of Bazyan: Historical and archaeological investigations", in K. Kopanias and J. MacGinnis, eds. The Archaeology of the Kurdistan Region in Iraq and Adjacent Regions. Oxford: Archeopress, pp. 11-18.

Andrae, W. and H. Lenzen. 1933. Die Partherstadt Assur. Wissenschaftliche Veröffentlichungen der Deutschen Orient-Gesellschaft 57. Leipzig: Hinrichs.

Ball, W. 2000. Rome in the East: The Transformation of an Empire. London: Routledge.

Bergamini, G. 1987. "Parthian Fortifications in Mesopotamia". Mesopotamia 22: 195-214.

Bivar, A. D. H. 1983. "The Political History of Iran Under the Arsacids", in E. Yarshater, ed. The Cambridge History of Iran, Vol. 3(I): The Seleucid, Parthian and Sasanian Periods. Cambridge: Cambridge University Press, pp. 21-99.

Boehmer, R. M. and H. von Gall. 1973. "Das Felsrelief bei Batas-Herir". Baghdader Mitteilungen 6: 65-77.

Curtis, V. S. 1998. "The Parthian Costume and Headdress", in J. Wiesehöfer, ed. Das Partherreich und seine Zeugnisse. Stuttgart: Steiner, pp. 61-73.

Debevoise, N. C. 1934. Parthian Pottery from Seleucia on the Tigris. Ann Arbor: University of Michigan Press. - 1938. A Political History of Parthia. Chicago: University of Chicago Press.

Dirven, L. 2008. "Aspects of Hatrene religion: A note on the statues of kings and nobles from Hatra", in T. Kaizer, ed. The Variety of Local Religious Life in the Near East in the Hellenistic and Roman Periods. Leiden: Brill, pp. 209-246.

Edmonds, C. J. 1952. "The place names of the Avroman parchments". Bulletin of the School of Oriental and African Studies 14: 478-482.

George, A. R. 2003. The Babylonian Gilgamesh Epic: Introduction, Critical Edition and Cuneiform Texts. Oxford: Oxford University Press.

Godley, A. D. 1920. Herodotus, Histories, with an English translation. Cambridge: Harvard University Press. 
Grabowski, M. 2011. "Abdissares of Adiabene and the Batas-Herir Relief”. Światowit. Annual of the Institute of Archaeology of the University of Warsaw 9: 117-140.

Graf, D. F. 1994. "The Persian royal road system”, in H. Sancisi-Weerdenburg, A. Kuhrt and M. Cool Root, eds. Achaemenid History VIII: Continuity and Change. Proceedings of the Last Achaemenid History Workshop April 6-8, 1990 - Ann Arbor, Michigan. Leiden: Nederlands Instituut Voor Het Nabije Oosten, pp. 167-189.

Ghirshman, R. 1962. Parthes et Sassanides. Paris: Gallimard.

Hauser, S. 1994. Chronologische und historisch-politische Untersuchungen zur östlichen Ğazīra in vorislamischer Zeit. Unpublished PhD dissertation, Freie Universität Berlin.

1996. "The production of Pottery in Arsacid Assur", in K. Bartl and S. R. Hauser, eds. Continuity and Change in Northern Mesopotamia from the Hellenistic to the Early Islamic Period. Berliner Beiträge zum Vorderen Orient 17. Berlin: Dietrich Reimer Verlag, pp. 55-85.

Haerinck, E. 1983. La céramique en Iran pendant la période Parthe (ca. 250 av. J.C. à 225 après J.C.). Typologie, chronologie et distribution. Iranica Antiqua Supplément 2. Gent: Universitaire Stichting van België.

Hopkins, C. 1942. "The Parthian Temple". Berytus VII: 1-18.

Hopkins, C. ed. 1972. Topography and Architecture of Seleucia on the Tigris. Ann Arbor: University of Michigan. Jordan, J. 1928. Uruk-Warka. Leipzig: Hinrichs.

Karim, K. H., G. A. Hamasur and S. M. Tofiq. 2000. "Qara-Chatan Rockslide in Pira-Magroon Anticline, Northeastern Iraq". Journal of Zankoy Sulaimani 3(1): 33-47.

Keall, E. J. 1977. "Qal'eh-i Yazdigird: The Question of Its Date". Iran 15: 1-9.

1982. "Qal'eh-i Yazdigird: An Overview of the Monumental Architecture". Iran 20: 51-72.

Keller, D. 2010. "Arsakidische Münzen”, in U. Hackl, B. Jacobs and D. Weber, eds. Quellen zur Geschichte des Partherreiches, Band 2: Griechische und lateinische Texte, Parthische Texte, Numismatische Evidenz. Studien zur Umwelt des Neuen Testaments 85. Göttingen: Vandenhoeck \& Ruprecht, pp. 613-632.

Kennedy, D. 1996. "Parthia and Rome: Eastern Perspectives", in D. L. Kennedy, ed. The Roman Army in the East. Journal of Roman Archaeology Supplementary Series 18. Ann Arbor: Journal of Roman Archaeology, pp. 67-90.

Khosrowzadeh, A. 2014. "The Parthian Settlements and Sites in Qeshm Island". Pazhohesh-ha-ye Bastanshenasi Iran 3(5): 79-100 (in Persian).

LeRider, G. 1965. Suse sous les Séleucides et les Parthes. Les trouvailles monétaires et l'histoire de la ville. Mémoires de la Mission Archéologique en Iran 38. Paris: Geuthner.

Le Strange, G. 1905. The Lands of the Eastern Caliphate: Mesopotamia, Persia, and Central Asia, from the Moslem Conquest to the Time of Timur. Cambridge: Cambridge University Press.

Levine, L. D. 1973. "Geographical Studies in the Neo-Assyrian Zagros". Iran 11: 1-27.

Mahdi, A. 1950. "Archaeological sites in the Surdash region of Sulaimaniyah province", Sumer 6: 231-243 (in Arabic).

Marciak, M. 2017. Sophene, Gordyene, and Adiabene: Three Regna Minora of Northern Mesopotamia Between East and West. Leiden: Brill.

Marciak, M. and R. S. Wójcikowski. 2016. "Images of Kings of Adiabene: Numismatic and Sculptural Evidence". Iraq 78: 79-101.

Mathiesen, H. E. 1992. Sculpture in the Parthian Empire: A Study in Chronology. 2 vols. Aarhus: Aarhus University Press.

Nováček, K. 2016. "Contextualizing Arbīl: Medieval urbanism in Adiabene”, in K. Kopanias and J. MacGinnis, eds. The Archaeology of the Kurdistan Region in Iraq and Adjacent Regions. Oxford: Archeopress. pp. 267-276.

Oates, D. and J. Oates. 1958. "Nimrud 1957: The Hellenistic Settlement”. Iraq 20(2): 114-157.

Palermo, R. 2010. "A Parthian Domestic Complex in Tell Barri", in R. Matthews and J. Curtis, eds. Proceedings of the 7th ICAANE (International Congress on the Archaeology of the Ancient Near East). Wiesbaden: Harrasowitz, pp. 637-646.

Rasheed, K. 2001. "The project of Mountain Piramagroon's relief replicas at Merquli and Rabana". Hazar Merd 18: 153-163 (in Kurdish).

Saber, A. S., Z. Rejeb and M. Altaweel. 2014. "Report on the Excavations at Merquly: the 2009 season”. Iraq 76: $231-244$.

Schlumberger, D. 1983. "Parthian Art", in E. Yarshater, ed. The Cambridge History of Iran, Vol. 3(I): The Seleucid, Parthian and Sasanian Periods. Cambridge: Cambridge University Press, pp. 1027-1054.

Schottky, M. 2006a. "Vonones", in H. Cancik and H. Schneider, eds. Brill's New Pauly Online. doi.org/10.1163/ 1574-9347_bnp_e12207650

2006b. "Vologaeses", in H. Cancik and H. Schneider, eds. Brill's New Pauly Online. doi.org/10.1163/15749347_bnp_e12207000

Sellwood, D. 1971. An Introduction to the Coinage of Parthia. London: Spink. 
Sissakian, V. K., and S. F. Fouad. 2014. Geological Map of Sulaimaniyah Quadrangle, Scale 1:250,000. 2nd ed. Baghdad: Iraq Geological Survey.

Speiser, E. A. 1926-1927. "Southern Kurdistan in the Annals of Ashurnasirpal and Today". Annual of the American Schools of Oriental Research 8: 1-41.

Tamm, A., J. Fassbinder, C. Fink, P. Borsdorf, R. Davtyan, E. Schmalenberger, L. Stier, B. Einwag and A. Otto. in press. “Arbeiten in Gird-i Kazhaw (Iraqi-Kurdistan) 2015-2017”. Mitteilungen der Deutschen OrientGesellschaft.

Tao, W. 2007. "Parthia in China: a Re-examination of the Historical Records", in V. S. Curtis and S. Stewart, eds. The Age of the Parthians. The Idea of Iran vol. 2. London: I.B. Taurus, pp. 87-104.

Venco Ricciardi, R. 1997. "Hatara, Livello 9 La Ceramica Ellenistica". Mesopotamia XXXII: 131-161.

Wilkinson, T. J. 2003. Archaeological Landscapes of the Near East. Tucson: University of Arizona Press.

Wright, H. E. 2004. "Pleistocene Glaciation of Iraq", in J. Ehlers and P. L. Gibbard, eds. Quaternary Glaciations Extent and Chronology Part III: South America, Asia, Africa, Australasia, Antarctica. Developments in Quaternary Sciences vol. 2. Amsterdam: Elsevier, pp. 215-216.

Zamua, D. A. 2009. “The Batas-Harir Rock Relief”. Subartu 3: 82-86 (in Kurdish).

Corresponding Author: Michael Brown

Institut für Ur- und Frühgeschichte und Vorderasiatische Archäologie

Heidelberg University

Sandgasse 7

D-69117 Heidelberg

Germany

m.brown@uni-heidelberg.de

Peter Miglus

Institut für Ur- und Frühgeschichte und Vorderasiatische Archäologie

Heidelberg University,

Germany

Kamal Rasheed

Sulaimaniyah Directorate of Antiquities

Kurdistan, Iraq

Mustafa Ahmed

Institut Français du Proche-Orient (IFPO)

Erbil

Kurdistan, Iraq

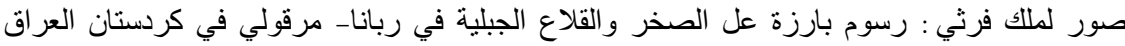

$$
\begin{aligned}
& \text { بقلم: مايكل براون، بيتز مجلوس، كمال رشيد ومصطفى احمد }
\end{aligned}
$$

نبذة مختصرة

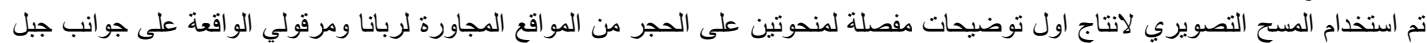

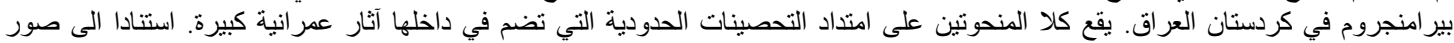

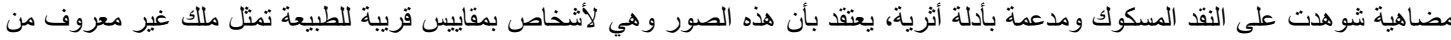

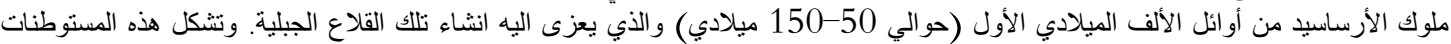

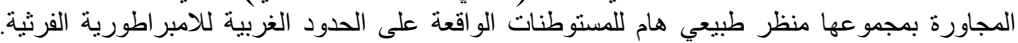

